\title{
IN-VITRO EVALUATION OF PHYTASE AND NEEM IN CHICKEN INTESTINAL EPITHELIAL CELLS
}

\author{
Azize Ayalew \\ Department of Biotechnology \\ School of Engineering and Technology, \\ Sharda University, Greater Noida, India
}

\author{
Pankaj Taneja \\ Associate Professor and HOD, \\ Department of Life Science, Basic science and \\ Research, Sharda University, Greater Noida, \\ India.
}

\begin{abstract}
Back ground and objective Phosphorus is presently discovered as a source of chicken diets in plant seeds. Phytic acid involves phosphorus, which is poorly digested, reduces use, and reduces metabolism and growth of chicken. Use of phytase and neem leaf extracts to enhance the use of phosphorus. Methodology: To prepare the neem leaves extract and commercial phytase used in the intestinal embryo chicken cell line to determine gene and enzyme activity using respectively molecular and biochemical characteristics. Trizol reagent used for RNA isolation, RNA assessment, cDNA synthesis, primary design in cellular regulatory genes, PCR amplification and RT-PCR sequences for molecular characterization. In biochemical characterization, we used protein lysis buffer to isolate protein, estimate protein by Lowry method, and assess the activity of the enzyme through alkaline phosphatase kit. The results were analyzed by two-way ANOVA test. Results: The findings of RT-PCR showed that the less time it took to amplify cDNA produces a high level of gene expression product in ALP, G6-P, Hexa kinase, $p 19$ and vice versa in p53, p21 cellular regulatory genes. The activity of the enzyme also showed an increase. The findings of the two-way ANOVA experiment showed that gene expression products were statistically significant $(p<0.005)$ in each cellular regulatory gene in the control and therapy group. Conclusion: Involvement of Cell Cycle Regulatory and Phosphate Metabolism Phytase and Neem Extract in Chickens ' diet can be useful for enhanced nutritional effectiveness, improved use, digestion of feed and growth of broilers as a direct hydrolytic result for phytate.
\end{abstract}

Key words - phytase, broiler chicken cell line, Neem leaves extract, phosphorous, and Gene expression

\section{INTRODUCTION}

Chicken is a group of domesticated birds for meat, eggs, and feathers kept by humans. Chicken manufacturing can lead to strategic revenue generation, enhancing indirect food safety pathways and mitigating disaster risk[Alders, R.Getal., 2009; Wong,J.Tetal.,2017], and Achieving without adverse effects on the, environment by combining manufacturing technologies with local agroecological technologies, using local and innovative feed formulations and ensuring that poultryfed food of human quality is used to create high dietary value secure poultry products[Kryger, K.Netal., 2010]. Ensure that all poultry products (meat and eggs) suitable for human consumption are used efficiently through surveillance of use along human and animal value chains[Wang $Z$, et al.,2009]. These birds make a contribution without delay to food security through domestic intake and circuitously through the sale of birds to help the achievement of other food objects, progressed family healthy situations and medicines [Wong, J. $\mathrm{T}$ et al.; 2017].

Phosphorus takes a vital character in the broilers metabolic and development procedures in the chicken's size and a nutrient that has the third uppermost profitable rate in broiler nourishment preparation next energy and amino acids, and its usage must be raised[Woyengo $\mathrm{T}$ A and Nyachoti M ,(2013); M LamidC et al.,2018].

Phytases are phosphatases that can hydrolyze one or more groups of phosphate from the phytate molecule [Tamim, N. M., 2004]. The phosphate released will be used as a source of phosphorus mineral deposits for livestock [Morse D H H and Wilcox D J, 1992], and the advantageous result of exogenous phytase in poultry nutrition is the complete hydrolytic outcome on the rise in the accessibility of phytate and minerals, amino acids, and energy [Selle $\mathrm{P} \quad \mathrm{H}$ and Ravindran V, 


\section{International Journal of Engineering Applied Sciences and Technology, 2019 \\ Vol. 4, Issue 6, ISSN No. 2455-2143, Pages 77-91 \\ Published Online October 2019 in IJEAST (http://www.ijeast.com)}

2007].Broiler diets consist basically of plantderived ingredients. These feeds are characterized by having a large part of phosphorus in the form of phytate [Falowo, A. B. (2015)], which is poorly hydrolyzed by monogastric animals [Tizziani, $\mathrm{T}$ et al.,2016], phytase enhances food digestibility, minimizing the anti-nutritional effects and promoting the productivity indices [HOOGE, D.M et al.,2010].

Exogenous phytase is included in feed formulations not only to reduce phosphorus supplementation, but also to release minerals, particularly calcium, as well as amino acids and carbohydrates by the hydrolysis of phytate, improving nutrient utilization [Oluyinka AO et al., 2008; Slominski BA et al., 2011].Plant materials are the major constituents of poultry diets. The ability of poultry and pigs to use phytate $\mathrm{P}$ is poor [ Ravindran, $\mathrm{V}$ et al,.2001; NRC, 1994; Ahmed, F et al., 2004],to insufficient quantities or lack of intestinal phytase secretion. This is due to lack of phytase, the enzyme that hydrolyses phytic acid into inositol and orthophosphate [Singh, P.K et al., 2008; Kaya, $M$ et al., 2009].Increasing of chicken's performance using supplemented exogenous enzymes with wheat and barley based diets is correlated to higher digestion and absorption rate of nutrients through the gut [Brenes, A et al., 1993a; Brenes, A et al., 1993b; Slominski BA et al., 2011; Kalantar, $\mathrm{M}$ et al., 2016] and has been related to increased gene expression of nutrient transporters such as glucose, amino acids and peptides [Gilbert, E. R et al., 2008a; Gilbert, E. R et al., 2008b; Agyekum, A.K et al., 2015]. Phytic acid acts as an anti-nutritional factor due to binding with starch, proteins and minerals, such as $\mathrm{P}, \mathrm{Zn}, \mathrm{Fe}, \mathrm{Ca}$ and Mg [Yang, Y.Y et al ., 2017]. Supplementation of phytase improves the nutritive value of feedstuffs by neutralization the negative effects such as intestinal villi atrophy, enlarged digestion organs and increased size of gastro intestinal tract [Cowieson, A. J et al., 2004; Ravindran, V et al., 2001; Kalantar, M et al., 2016].

Neem (Azadirachta indica) which is commonly called 'Indian Lilac' or 'Margosa', belongs to the family Meliaceae, subfamily Meloideae and tribe Melieae A. indica is a fast growing evergreen tree which has a potential to provide medicinal and nutritive value to broilers [Schmutterer $\mathrm{H}$, (1990)] . Broilers given neem leaf extract in water show progressed nutrient verbal exchange performance and weight gain [Mahejabin, $\mathrm{N}$ et al., 2015)].

Therefore, the main objective of our research paper to prepared the neem leaf extract for chicken diet and purchased commercial phytase, to evaluate the growth pattern of treated and untreated groups, evaluate genome profiling and the phosphorylation path way activities in broiler chicken cell line by molecular and biochemical characterization to determine the gene and enzyme activity respectively. Now that the gene expression and enzymatic activity with the sample of phytase and neem extract done in vitro chicken cell line successfully achieved, in the future recommend will be practice in vivo methods for the demonstration of all regulatory genes it should be possible to obtain further insights in the function of phosphorylation pathway in the metabolism of cells.

\section{MATERIALS AND METHODS}

Materials: This study used the fresh Neem Leaves Powder prepared, Extract and commercial phytase enzyme, Phytic Acid, Nutritional medium, Intestinal Embryo Chicken Cell Line, different lab reagent and equipment.

\subsection{Preparation of Neem Leaves extract \\ 2.2 Sample Collection and solvent extract}

Leaves were gathered from nearby greater Noida knowledge park III, Sharda university Azadirachta indica tree and safely taken in biotechnology laboratory for further experimental analysis. The plant was ensured to be safe and uninfected. Under running tap water, the leaves were washed to remove dust and other foreign particles and to carefully dry the leaves and keep some new leaves dried under the shadow.

The dried and fresh leaves were crushed into tiny parts, powdered and individually blended in the aforementioned powder samples $(30 \mathrm{~g})$ were suspended in ethanol $(150 \mathrm{ml})$ and kept at room temperature for $4 \mathrm{hr}$. The first blend was then filtered using a Bruckner funnel with what man filter paper No.1 was used and again $75 \mathrm{ml}$ ethanol was added at room temperature in the remaining residual powder in the first conical flask and filtered after 24 hours. In a round-bottom flask using a water bath, the first and second blended ethanol solvent evaporated from the filtrate were then space dried at $60^{\circ} \mathrm{c}$ up to $20 \mathrm{mg}$ dried weight remaining using water bath. The concentrate was then stored for further research at $4^{\circ} \mathrm{C}$. 


\section{International Journal of Engineering Applied Sciences and Technology, 2019 \\ Vol. 4, Issue 6, ISSN No. 2455-2143, Pages 77-91 \\ Published Online October 2019 in IJEAST (http://www.ijeast.com)}
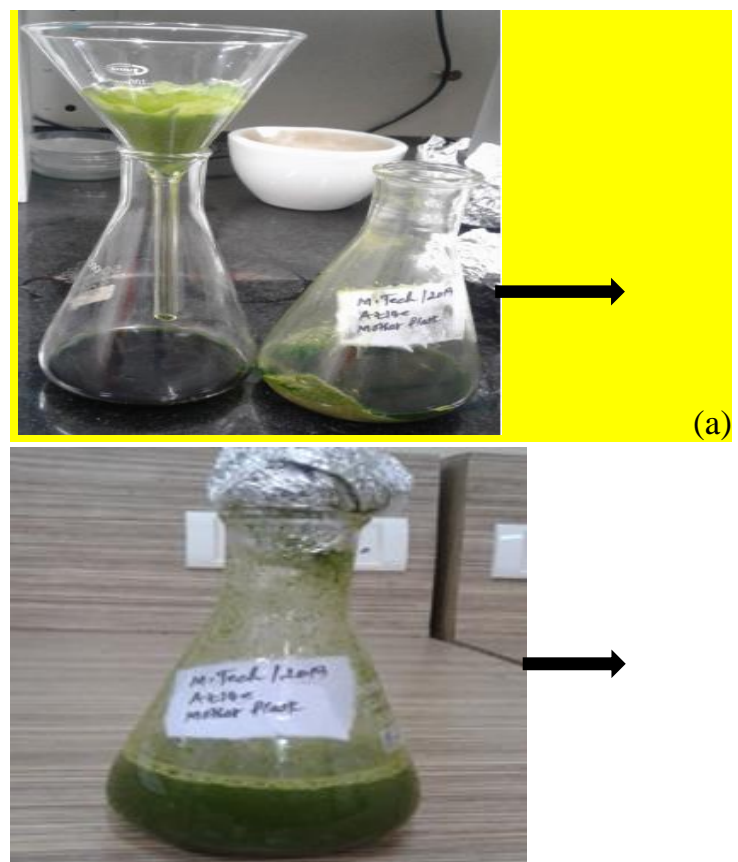

(b)

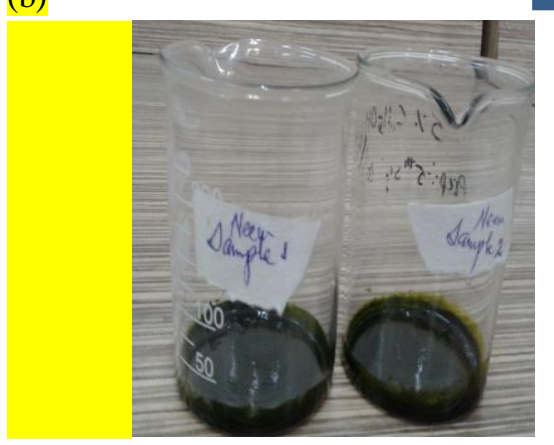

(c)

Figure1(a) Ethanol solvent neem leaves powder filtration (b) filtered from solution (c) dried with water bath powder

\subsection{Chicken cell line and experimental design:}

3.2.1 Molecular gene Characterisation and Biochemical Enzyme Activity

Intestinal Embryo Chicken Cell Line was used in this study. Intestinal embryo chicken's Cell line was purchased from National Center Cell Science NCCS Pune. Experimental procedures were performed in accordance with Cells were allocated into 6 well plates in molecular gene characterization and 6 well plates biochemical enzyme activity. All the treatment groups :-In the Sixth treatment each well plate $400 \mu \mathrm{l}$ cell line, $3 \mathrm{ml}$ PRMI Media, and $200 \mu 1$ Phytic Acid were culture incubated at $37^{\circ} \mathrm{C}$ and $5 \% \mathrm{CO} 2$ for 10 days to allow differentiation of chicken cell growth ; culture medium was then added with the corresponding condition medium containing phytic acid in all well plate medium and the first well plate is the control medium no added any supplement, the second well plate added neem extract $50 \mu \mathrm{l}$, the third well neem extract $100 \mu \mathrm{L}$ ,the fourth well plate phytase $50 \mu \mathrm{g}$, the fifth well plate phytase $100 \mu \mathrm{L}$, and the sixth well plate phytase $50 \mu \mathrm{l}$ plus neem extract $50 \mu \mathrm{l}$ mixed composition . PRMI Media was purchased from Gibco Company once.

3.2.2 Examination of the molecular features and biochemical activity of cell line intestinal embryo chicken

After 10 days of cultivation with phytase and neem leaf extract, the cells centrifuged the culture medium $4000 \mathrm{rpm}$ for 10 minutes and discarded the supernatant, the pellet washed as soon as PBS solutionand4000 rpm centrifuge for 10 minutes. The supernatant was finally withdrawn. The molecular characteristics and biochemical activity of the intestinal chicken cell with $800 \mu \mathrm{L}$ Trizol reagent and $1 \mathrm{ml}$ protein lysis buffer with $100 \mu \mathrm{L}$ proteas inhibitor were then examined respectively.

\subsubsection{Molecular characterisation of gene activities}

\subsubsection{RNA Isolation}

The medium-added incubated intestinal chicken cell line leaves 10 days of extract and phytase. Then all samples were homogenized and $4000 \mathrm{rpm}$ centrifuged at 10 minutes. Then the supernatant was discarded with $1 \mathrm{ml}$ pippete, the pellet washed with $2 \mathrm{ml}$ PBS solution and $4000 \mathrm{rpm}$ centrifuged at 10 minutes. In $800 \mu \mathrm{L}$ Trizol reagent, the washing cell pellet dissolved and incubated at room temperature for 10 minutes to enable full dissociation of nucleoprotein complexes. At 15 minutes, after incubation, added $300 \mu \mathrm{L}$ of chloroform and $7000 \mathrm{rpm}$ of centrifuge. The sample mixture centrifugation should be separated into three phases. Total RNA was contained in the colorless aqueous phase of the TOP layer. Then the aqueous stage was thoroughly carried out using a big pippete in a fresh sterile eppendrof tube. Added $700 \mu \mathrm{L}$ isopropanol in aqueous stage as inventory solution and blended softly, leave for 10 minutes at room temperature. Next centrifuged the RNA on the side and bottom of the pipe at maximum velocity of $14000 \mathrm{rpm}$ for 15 minutes. Using the pippete, the supernatant was separated in the waste container and the RNA pellet washed at $8000 \mathrm{rpm}$ for $10 \mathrm{~min}$ by adding 80 percent ethanol and centrifuge. Air dried RNA pellet for 10 minutes and dissolved next stored in $-800 \mathrm{c}$ refrigerators in $30 \mu \mathrm{L}$ distilled water. 


\section{International Journal of Engineering Applied Sciences and Technology, 2019 \\ Vol. 4, Issue 6, ISSN No. 2455-2143, Pages 77-91 \\ Published Online October 2019 in IJEAST (http://www.ijeast.com)}

\subsubsection{Estimation of RNA concentration}

Estimation of RNA concentration from the RNA isolation following $5 \mu \mathrm{L}$ of the sample combined with $995 \mu \mathrm{L}$ of each sample distilled water. Then take the Absorbance reading by $260 \mathrm{~nm}$ in the individual samples. The RNA concentration of each sample was calculated by OD reading*40 $\mu \mathrm{g}$ / $\mathrm{ml}$ *dilution factor of each sample at the end of the reading. Finally, the complete RNA in the incubated chicken cell line is calculated using $4 \mu \mathrm{L}$.

\subsubsection{First Strand cDNA Synthesis}

Mix and briefly centrifuge the kit parts after thawing. The first technique added sterile tube reagents to Template RNA calculated from Total RNA $4 \mathrm{~g}$, the second method prepared Master Mix $147 \mu \mathrm{L} / 7=21 \mu \mathrm{L}$ parts of Water $12 \mu \mathrm{l} /$ Each Sample Tube(7), Oligo(dT)18 Primer $1 \mu \mathrm{l} /$ Each Sample Tube,5x Reaction Buffer $4 \mu \mathrm{L}$ / Each Sample Tube, Ribo Lock Rnase inhibitor $(20 \mathrm{u} / \mu \mathrm{L}) 1 \mu \mathrm{L} /$ Each sample tube, $10 \mathrm{mM}$ dNTP mix $2 \mu \mathrm{L} /$ Each sample tube, Revert Aid M-MULVRT(200u/ $\mu \mathrm{L}) 1 \mu \mathrm{L} /$ Each sample tube and the third process to add 20 $\mu \mathrm{L}$ Master Mix Solution for each sample with master mix control (7 samples). Thermo Fischer Scientific's cDNA kit.

\subsubsection{Gene Primer Design}

A primer is a short synthesized oligonucleotide used in many molecular methods from PCR to DNA sequencing. These primers are designed to have a sequence that is the reverse complement of a DNA region that we want to anneal to the primer sequence analysis model or target. The first you design has an effect on the DNA amplification stage as a whole. DNA polymerases, the enzymes that catalyze DNA replication, can only be initiated by adding nucleotides to the primers. Therefore, an effective amplification of DNA is required A main enzyme called primase, which is a kind of RNA polymerase, must be synthesized before DNA replication can occur, because DNA synthesizing enzymes, called DNA polymerases, can only add new DNA nucleotides to a present nucleotide strand. The gene priming design measures followed by the use of the global web national biotechnology institute center (www.ncbi.nih.gov) to the gene page discovered six cellular regulatory genes in the domestic chicken (Gallus gallus chicken). After that each cellular regulatory gene sequence mRNA was searched, the new sequence was linked and the region of coding clicked. Then pick, copy and place the origin a sequence on the website of Gene Script PCR Primer Design, Paste (sequence space), Pick Primer and Primer Design. After completion of downloading each cellular regulatory gene's forward and reverse sequence, choose the finest primer design.

\subsubsection{The PCR Amplification and RT-PCR Sequences}

The first strand cDNA synthesis product can be used in PCR or qPCR straight. The first strand cDNA synthesis reaction mixture quantity should not exceed $1 / 10$ of the complete amount of PCR reaction. Normally, $2 \mu \mathrm{L}$ of the first cDNA synthesis response blend is used in $50 \mu \mathrm{L}$ complete volume as a template for successive PCR.

The PCR cycling parameters were predenaturation at $95^{\circ} \mathrm{C}$ for $10 \mathrm{~min} ; 35$ cycles $\left(94^{\circ} \mathrm{C}\right.$ for 30 seconds denaturation; $60^{\circ} \mathrm{C}$ for 30 seconds annealing; and $72^{\circ} \mathrm{C}$ extension for 60 seconds) and a final extension at $72^{\circ} \mathrm{C}$ for 5 minutes. The RT-PCR cDNA sequences made by the Delhi Nuclear Medicine and Allied Science Institute (INMAS). Biosystem Applied. CTX Machine CDNA (GenBank mRNA number: Xm 015292141.2 for the p53 gene, Xm 004941288.2 for the p21 gene, Xm 025146627.1 for the ALP gene, $\mathrm{Nm} 001038693.2$ for the G-6-P gene, Nm 204101.1 for the Hexo kinase gene, and Xm 003643958.4 for the p19 gene) has been enhanced by PCR with $\mathrm{F} 1$ and $\mathrm{R} 1$ primers,F4 and R4 primers, F3 and R3 primers, F4 and R4 primers, F3 and R3 primers, and F4 and R4 primers respectively (Table 4) built on the basis of the 5'and 3'-Real Time-PCR amplification product sequence data.

All PCR amplification products were electro phoresized to an agarose liquid of 1.2 percent comprising Gel Green Nucleic Acid Gel Stain, $10,000 \mathrm{X}$ at the DMSO Institute of Nuclear Medicine and Allied Science (INMAS), Delhi. Applied biological system. CTX Machine and extracted from the agarose gel using a Fast Gene Gel / PCR Extraction Kit (INMAS), Delhi) followed by sequence assessment.

\subsubsection{Biochemical enzyme activity}

In biochemical enzyme activity, experimental processes were conducted in accordance with the allocation of cells to six wells plate. To assess the phytase and Neem extract to determine the activity of the phosphorylation pathway in the cell line. Phosphorylation is the method of introduction into an organic molecule of a phosphate group. It plays a key role in regulating cellular procedures such as cell apoptosis, cycle, development and signal transduction pathways. Enzymes are proteins in front of protein-based drugs otherwise catalyze drug responses to promote race happy. Enzymes are particularly distinctive, being used highly 
selectively for substrates at home (substance before molecules on which they have an impact) also in the name of the finished harvest they generate. From the moment enzymes are proteins, they are vulnerable before destruction close digestive enzymes in the direction of likely denaturation, regardless of which can promote alteration of their structure. Typically, enzymes have superlative environments (temperatures, $\mathrm{pH}$, etc.) somewhere they run gamely new.

\subsubsection{Isolation of Protein}

The extraction methods followed are described in the samples added in the medium Neem extract and phytase were first incubated on $37^{\circ} \mathrm{c}$ in the $\mathrm{CO}_{2}$ incubator for 10 days, mixed with overtaxing, and centrifuged the medium $4000 \mathrm{rpm}$ for $10 \mathrm{~min}$ all samples. Then the supernatant was discarded, the pellet washed with $2 \mathrm{ml}$ PBS solution and the solution centrifuged again for 10 minutes by 4000 rpm. Protein standards have been prepared with $1 \mathrm{ml}$ protein lysis buffer plus $100 \mu \mathrm{l}$ protease inhibitor (cocktail tablet). After centrifuging 10000 rpm for $15 \mathrm{~min}$, it took the supernatant and stored $20^{\circ} \mathrm{c}$ fridges to use the estimated concentration of protein and activity of the enzyme.

3.2.4.2 Procedures Protein Estimation by Lawry Method

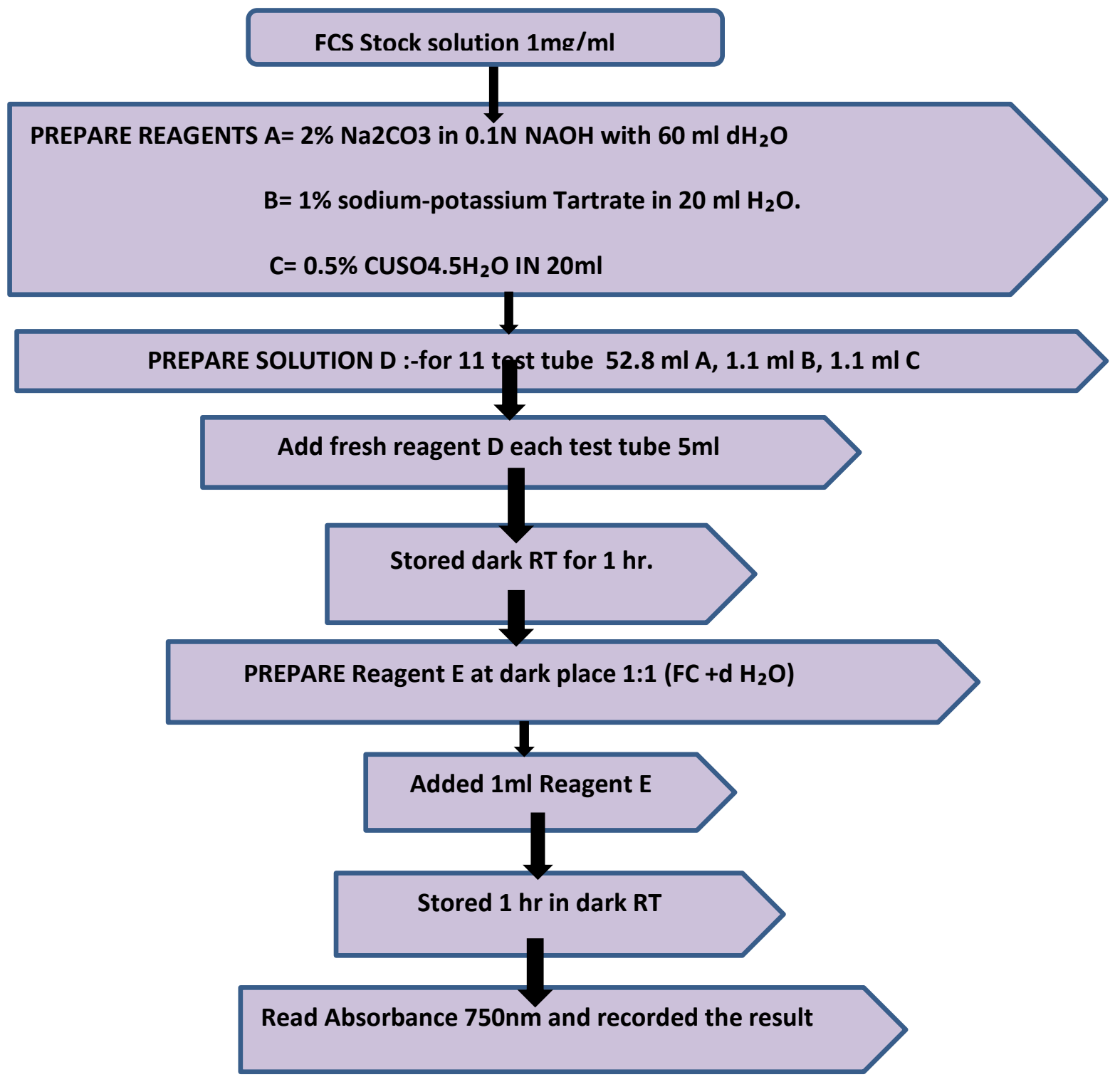




\section{International Journal of Engineering Applied Sciences and Technology, 2019 \\ Vol. 4, Issue 6, ISSN No. 2455-2143, Pages 77-91 \\ Published Online October 2019 in IJEAST (http://www.ijeast.com)}

Figure 2The procedure of the estimation protein concentration from the isolated protein by Lowry method

\subsubsection{Alkaline phosphatase KIT (ALP)}

A minor protein on the brush's boundary, ALP is a very vibrant enzyme that can easily be measured in tissue and cell homogeneity, making it the preferred marker for early research in-vitro intestinal cell growth (Moog, Fetal., 1953, Koldovsky.0etal.,1969, HenningS.Jetal.,1985).ALP activity has been used to mean frequently mobile intestinal epithelial strains, but the intestinal ALP can be handled with isoforms found in other tissues,

cells and body fluids. cDNA and genes coding for a distinctive ALP bureaucracy have been cloned and can be used to collect particular samples to that extent theoretically. Enzymes were the largest monoclonal antibodies in the intestinal system and each pig was distinctive (Quaroni, A et al., 1985).

The alkaline phosphatase kit used to evaluate enzyme activity was performed at $100 \mu \mathrm{g}$ per protein blended sample With $900 \mu$ of alkaline phosphatase buffer kit and $50 \mu$ l of Para Nitro phenol (substrate) added $5 \mu$ l of ALP enzyme next to incubated overnight at 370c, yellow-colored enzyme activity was shown to be present and absorbance read at $405 \mathrm{~nm}$.

\section{STATISTICAL ANALYSIS}

The cellular regulatory gene activities and enzymatic activity concentration of the intestinal Embryonic broiler chicken cell line were analyzed quantitatively by two-way ANOVA test and excel respectively.

\section{RESULTS}

To explain the RT-PCR Results. The cDNA sequences of the RT-PCR done- Institute of Nuclear Medicine and Allied Science (INMAS), Delhi. Applied Biosystem. CTX Machine a highly sensitive technique for the detection and quantitation of mRNA (messenger RNA). The technique consists of two parts: The synthesis of cDNA (complementary DNA) from RNA by reverse transcription (RT), and the amplification of a specific cDNA by the polymerase chain reaction (PCR) in chicken cell line the different regulatory gene to correlated the average CT Value target untreated and in the home keeping gene (GADPH) target untreated with the average CT Value target treated and in the home keeping gene (GADPH) target treated compared with the fold change functional gene expression product with in each samples treatment (control, Neem extract and phytase supplement) and within six cell regulatory gene product in chicken cell line cultured with phytase and neem leaves extract.

5.1 The role and functions of regulatory gene protein

A gene that regulates, or regulates is a gene that regulates the expression of one or more other genes. Regulatory sequences encoding regulatory genes are often 5' to the point of transcription of the gene they control. Regulatory sequence checks when and where protein expression happens. The promoter and enhancer regions regulate the gene transcription into a modified pre mRNA to remove introns and add a $5^{\prime}$ cap and a dark gray poly-A tail.

Gene expression regulation or gene regulation encompasses a broad variety of mechanisms that cells use to boost or reduce the output of particular gene products (protein or RNA). The protein function depends on the form of the protein. The amino acid order determines the shape of the protein. The protein information is encoded in the cell's DNA. When a protein is generated and this copy is transferred to a ribosome, a copy of the DNA is made.

\subsubsection{P53 gene activity}

The critical event that leads to the activation of p53 is its $\mathrm{N}$-terminal domain phosphorylation. The $\mathrm{N}$ terminal transcriptional activation domain includes a big amount of phosphorylation locations and can be regarded as the primary target for kinases of protein that transmit stress signals.

P53 is activated in reaction to a multitude of stressors, including but not restricted to damage to DNA, oxidative stress, ( Hendriks, G et al., 2015) . Activated p53 binds DNA and activates multiple gene expression, including microRNA miR34a, National Biotechnology Information Center (Su, W et al., 2014). The RT-PCR result of p53 gene in the Average CT(target, untreated )value and Average CT (ref-GAPDH, untreated) with the average target treated cycling threshold and Average CT(refGAPDH, treated) values were almost the same CT value number in control treatment and (in neem 50 $\mu \mathrm{L}$, neem $100 \mu \mathrm{L}$ ) decreased, phytase $50 \mu \mathrm{L}$, phytase $100 \mu \mathrm{L}$, and phytase $50 \mu \mathrm{L}$ plus neem 50 $\mu \mathrm{L}$ sample treatment cycling threshold value increased and to the reverse the fold change functional gene expression product( in neem $50 \mu \mathrm{L}$, neem $100 \mu \mathrm{L}$ ) increased, other sample treatment decreased respectively. 


\section{International Journal of Engineering Applied Sciences and Technology, 2019 \\ Vol. 4, Issue 6, ISSN No. 2455-2143, Pages 77-91 \\ Published Online October 2019 in IJEAST (http://www.ijeast.com)}

\subsubsection{The P21 Gene activity}

The p21 gene includes several p53 response elements that mediate direct binding of the p53 protein, leading in the $\mathrm{p} 21$ protein encoding gene being transcriptionally activated. P21 (CDKN1A) belongs to a cell cycle-dependent family of kinase inhibitors. P21 modulates distinct mechanisms, including cell development, differentiation (CU, P., \& GAO, C. F. (2009).) and apoptosis

P21 is a persuasive kinase inhibitor (CKI) dependent on cycline. The protein p21 (CIP1/WAF1) also inhibits the leisure value of cyclin-CDK2, -CDK1, moreover -CDK4/6 complexes, while a group series director next to G1 also works in this manner. Cdks gesture the chamber through phosphorylation with the aim of organizing it just before the lob interested in the chamber cycle after that point. Cycling-dependent protein kinases, as their call indicates, are dependent next to cyclins, an extra lecture on authoritarian proteins. Cyclins join Cdks, activating additional molecules near phosphorylate. P21 is expressed in a constitutive and cell cycledependent way in the proliferation of cells at a basal level, (Siddik, Z. H. (Ed.). (2010). Therefore, whenthe RT-PCR result of $\mathrm{p} 21$ gene in the Average CT(target, untreated )value and Average CT (refGAPDH, untreated) with the average target treated cycling threshold and Average CT(ref-GAPDH, treated) values were almost the same $\mathrm{CT}$ value number in control treatment and (in neem $50 \mu \mathrm{L}$, neem $100 \mu \mathrm{L}$, phytase $50 \mu \mathrm{L}$, phytase $100 \mu \mathrm{L}$ ware increased, and phytase $50 \mu \mathrm{L}$ plus neem 50 $\mu \mathrm{L}$ sample treatment cycling threshold value was decreased and to the reverse the fold change functional gene expression product in neem $50 \mu \mathrm{L}$, neem $100 \mu \mathrm{L}$, phytase $50 \mu \mathrm{L}$, phytase $100 \mu \mathrm{L}$ decreased, sample treatment phytase $50 \mu \mathrm{L}$ plus neem $50 \mu \mathrm{L}$ was increased respectively.

\subsubsection{The glucose-6- phosphatase}

This enzyme, which is vigorously trendy for all cell kinds and purposes, is elaborate when carbohydrates are dissolved as normal. This enzyme helps prevent premature destruction of crimson blood cells.G6PD deficiency is a genetic idiosyncrasy with an inadequate amount of glucose6phosphate dehydrogenase (G6PD) common in the blood to produce a fashionable result. This is an enormously precious enzyme (or protein) with the purpose of regulating numerous biochemical responses within the body. It is accepted that this primitive destruction of ruby blood cells has the status of hemolysis, next it can lead to hemolytic anemia in the end guide. The underlying trigger has long been handled before it has been resolved, symptoms of G6PD deficiency usually pass away surrounded by a few weeks. G6PD deficiency is a genetic clause for which parents close their kid are recognized as single otherwise mutually.

The RT-PCR result of the glucose-6- phosphatase gene activity in the Average CT(target, untreated ) value and Average CT (ref-GAPDH, untreated) with the average target treated cycling threshold and Average CT(ref-GAPDH, treated) values were almost the same CT value number in control treatment and in neem $50 \mu \mathrm{L}$, neem $100 \mu \mathrm{L}$ were increased, phytase $50 \mu \mathrm{L}$, phytase $100 \mu \mathrm{L}$, phytase $50 \mu \mathrm{L}$ plus neem $50 \mu \mathrm{L}$ sample treatment cycling threshold value was decreased and to the reverse the fold change functional gene expression product in neem $50 \mu \mathrm{L}$, neem $100 \mu \mathrm{L}$ decreased and phytase $50 \mu \mathrm{L}$, phytase $100 \mu \mathrm{L}$, phytase $50 \mu \mathrm{L}$ plus neem $50 \mu \mathrm{L}$ were highly increased respectively.

\subsubsection{The Hexo Kinase Gene activity}

A hexokinase is an enzyme that facilitates the formation of hexose phosphorylates. Hip the majority of humans, glucose, in relation to glucose6phosphate, is the most significantly important product. During the firstly pace of glycolysis, the glucose mob is phosphorylated. Phosphorylation is the handle of tallying a phosphate assemble near a molecule consequential beginning ATP. The upshot occurs amid the relief of the enzyme hexokinase, an enzyme so as to catalyze the phosphorylation of a lot of sixmembered glucose-likechimestructures. Hexokinase. The chief movement in vogue glycolysis is a priming reaction; someplace a phosphate congregate is extra on the road to glucose via ATP. This outcome is notable instead of its capability on the way to con glucose contained by the cell. Hexokinase activates glycolysis near phosphorylating glucose. The RTPCR result of the glucose-6- phosphatase gene activity in the Average CT(target, untreated) value and Average CT (ref-GAPDH, untreated) with the average target treated cycling threshold and Average CT(ref-GAPDH, treated) values were almost the same CT value number in control treatment and in neem $100 \mu \mathrm{L}$ phytase $50 \mu \mathrm{L}$, were increased, neem $50 \mu \mathrm{L}$, , phytase $100 \mu \mathrm{L}$, phytase $50 \mu \mathrm{L}$ plus neem $50 \mu \mathrm{L}$ sample treatment cycling threshold value was decreased and to the reverse the fold change functional gene expression product in neem $100 \mu \mathrm{L}$ phytase $50 \mu \mathrm{L}$, decreased and neem $50 \mu \mathrm{L}$, phytase $100 \mu \mathrm{L}$, phytase $50 \mu \mathrm{L}$ plus neem $50 \mu \mathrm{L}$ were highly increased respectively.

\subsubsection{The P19 Gene activity}

The p19 protein binds to double-stranded RNAs that function as short interfering RNA (siRNA) and 


\section{International Journal of Engineering Applied Sciences and Technology, 2019 \\ Vol. 4, Issue 6, ISSN No. 2455-2143, Pages 77-91 \\ Published Online October 2019 in IJEAST (http://www.ijeast.com)}

is specialized for the 21-nucleotide product of the enzyme DCL4 (a member of a family of plant enzymes with homology to Dicer) (Csorba, $\mathrm{T}$ et al., 2009). Consequently, the selective sparing of its repressor from the overall sequestration of miRNA by 19 reduces cellular AGO1 concentrations and constitutes an extra mechanism by which p19 inhibits silencing (Hipper, C et al., 2013), Várallyay E et al., 2010). The two mechanisms are mutually autonomous and can be abrogated selectively (Alers, S et al., 2012).

The RT-PCR result of the P19 Gene activity in the Average CT(target, untreated ) value and Average CT (ref-GAPDH, untreated) with the average target treated cycling threshold and Average CT(refGAPDH, treated) values were the same CT value number in control sample treatment and in neem 50 $\mu \mathrm{L}$, neem $100 \mu \mathrm{L}$, phytase $50 \mu \mathrm{L}$, phytase $100 \mu \mathrm{L}$, phytase $50 \mu \mathrm{L}$ plus neem $50 \mu \mathrm{L}$ sample treatment cycling threshold value were decreased and to the reverse in neem $50 \mu \mathrm{L}$, neem $100 \mu \mathrm{L}$, phytase 50 $\mu \mathrm{L}$, phytase $100 \mu \mathrm{L}$, phytase $50 \mu \mathrm{L}$ plus neem 50 $\mu \mathrm{L}$ the fold change functional gene expression product were increased respectively.

\subsubsection{The Alkaline phosphatase Gene activity}

Alkaline phosphatase is an ubiquitous membranebound glycoprotein that catalyzes the hydrolysis of phosphate monoesters at basic $\mathrm{pH}$ values. Alkaline phosphatases are plasma membrane-bound glycoproteins. These enzymes are widely distributed in nature, including prokaryotes and higher eukaryotes with the exception of some higher plants. Alkaline phosphatase forms a large family of dimeric enzymes, usually confined to the cell surface hydrolyzes various monophosphate esters at a high $\mathrm{pH}$ optimum with release of inorganic phosphate.

The gene encoding for intestinal ALP (IAP) is a member of the gene family mapping to the long arm of chromosome 2, IALP is partially heat-stable isozyme present at high levels in intestinal tissue. In contrast to the other ALP isoenzymes, the carbohydrate side-chains of IAP are not terminated by sialic acid.

The RT-PCR result of the Alkaline phosphotasegene activity in the Average CT(target, untreated ) value and Average CT (ref-GAPDH, untreated) with the average target treated cycling threshold and Average CT(ref-GAPDH, treated) values were the same $C T$ value number in control sample treatment and in neem $50 \mu \mathrm{L}$, neem $100 \mu \mathrm{L}$, phytase $50 \mu \mathrm{L}$, phytase $100 \mu \mathrm{L}$, phytase $50 \mu \mathrm{L}$ plus neem $50 \mu \mathrm{L}$ sample treatment cycling threshold value were decreased and to the reverse the fold change functional gene expression product in neem $50 \mu \mathrm{L}$, neem $100 \mu \mathrm{L}$, phytase $50 \mu \mathrm{L}$, phytase 100 $\mu \mathrm{L}$, phytase $50 \mu \mathrm{L}$ plus neem $50 \mu \mathrm{L}$ were highly increased respectively.

Table:-1 The RT-PCR results of average cycling threshold value of the target, untreated samples with the average cycling threshold ref-GAPDH, untreated (home keeping gene) compared with the fold change gene expression effect. The cDNA sequences of the RT-PCR done- Applied Biosystem. CTX Machine.

\begin{tabular}{|c|l|l|l|l|l|l|}
\hline P53 & $\begin{array}{l}\text { Average } \\
\text { CT(target, } \\
\text { untreated) }\end{array}$ & $\begin{array}{l}\text { Average } \\
\text { CT(ref- } \\
\text { GAPDH, } \\
\text { untreated) }\end{array}$ & $\begin{array}{l}\text { Average } \\
\text { CT(target, } \\
\text { treated) }\end{array}$ & $\begin{array}{l}\text { Average } \\
\text { CT(ref- } \\
\text { GAPDH, } \\
\text { treated) }\end{array}$ & DeltaDeltaCT & $\begin{array}{l}\text { Fold change Gene } \\
\text { Expression }\end{array}$ \\
\hline $\begin{array}{c}\text { A Untreated } \\
\text { Control }\end{array}$ & 27.20 & 23.14 & 27.20 & 23.14 & 0 & 1 \\
\hline B Neem -50 & & & 27.16 & 23.14 & 0.05 & 1.036587801 \\
\hline C Neem -100 & & & 27.13 & 23.08 & 0.02 & 1.015021102 \\
\hline D Phytase-50 & & & 27.56 & 23.19 & -0.31 & 0.805707793 \\
\hline E Phytase-100 & & & 27.52 & 23.10 & -0.35 & 0.784383301 \\
\hline $\begin{array}{l}\text { F Neem(50) } \\
\text { Phytase (50) }\end{array}$ & & & 27.77 & 23.20 & -0.50 & 0.707847127 \\
\hline $\begin{array}{c}\text { P21 Average CT } \\
\text { (target, } \\
\text { untreated) }\end{array}$ & $\begin{array}{l}\text { Average CT } \\
\text { (ref-GAPDH, } \\
\text { untreated) }\end{array}$ & $\begin{array}{l}\text { Average } \\
\text { CT(target, } \\
\text { treated) }\end{array}$ & $\begin{array}{l}\text { Average } \\
\text { CT(ref- } \\
\text { GAPDH, } \\
\text { treated) }\end{array}$ & & DeltaDeltaCT & $\begin{array}{l}\text { fold change Gene } \\
\text { Expression }\end{array}$ \\
\hline $\begin{array}{c}\text { A Untreated } \\
\text { Control }\end{array}$ & 27.10 & 23.14 & 27.10 & 23.14 & 0.007431391 & 1.005164337 \\
\hline B Neem -50 & & & 27.16 & 23.21 & 0.02 & 1.015255133 \\
\hline C Neem -100 & & & 27.13 & 23.11 & -0.05 & 0.966947671 \\
\hline D Phytase-50 & & & 27.16 & 23.24 & 0.04 & 1.026923431 \\
\hline E Phytase-100 & & & 27.44 & 23.17 & -0.30 & 0.812044519 \\
\hline
\end{tabular}


Published Online October 2019 in IJEAST (http://www.ijeast.com)

\begin{tabular}{|c|l|l|l|l|l|l|}
\hline $\begin{array}{c}\text { F Neem(50) + } \\
\text { Phytase (50) }\end{array}$ & & & 26.97 & 23.27 & 0.27 & 1.204838244 \\
\hline $\begin{array}{l}\text { Glucose-6- } \\
\text { Phosphatase }\end{array}$ & $\begin{array}{l}\text { Average CT } \\
\text { (target, } \\
\text { untreated) }\end{array}$ & $\begin{array}{l}\text { Average CT } \\
\text { (ref-GAPDH, } \\
\text { untreated) }\end{array}$ & $\begin{array}{l}\text { Average } \\
\text { CT(target, } \\
\text { treated) }\end{array}$ & $\begin{array}{l}\text { Average } \\
\text { CT(ref- } \\
\text { GAPDH, } \\
\text { treated) }\end{array}$ & DeltaDeltaCT & $\begin{array}{l}\text { Fold chpression } \\
\text { Exe Gene }\end{array}$ \\
\hline $\begin{array}{c}\text { A Untreated } \\
\text { Control }\end{array}$ & 27.32 & 23.14 & 27.10 & 23.14 & 0.225820305 & 1.169441995 \\
\hline B Neem -50 & & & 27.16 & 23.21 & 0.24 & 1.181181966 \\
\hline C Neem -100 & & & 27.25 & 23.11 & 0.04 & 1.030462675 \\
\hline D Phytase-50 & & & 25.16 & 23.24 & 2.26 & 4.779029025 \\
\hline E Phytase-100 & & & 25.25 & 23.17 & 2.11 & 4.310991272 \\
\hline $\begin{array}{c}\text { F Neem(50) } \\
\text { Phytase (50) }\end{array}$ & & & 24.52 & 23.27 & 2.94 & 7.659384077 \\
\hline
\end{tabular}

\begin{tabular}{|c|c|c|c|c|c|c|c|}
\hline $\begin{array}{c}\text { Alkaline } \\
\text { Phosphatase }\end{array}$ & $\begin{array}{l}\text { Average CT } \\
\text { (target, } \\
\text { untreated) }\end{array}$ & $\begin{array}{l}\text { Average CT } \\
\text { (ref-GAPDH, } \\
\text { untreated) }\end{array}$ & $\begin{array}{l}\text { Average } \\
\text { CT(target, } \\
\text { treated) }\end{array}$ & $\begin{array}{l}\text { Average } \\
\text { CT(ref- } \\
\text { GAPDH, } \\
\text { treated) }\end{array}$ & DeltaDeltaCT & $\begin{array}{l}\text { fold change } \\
\text { Expression }\end{array}$ & Gene \\
\hline $\begin{array}{cc}\text { A } & \text { Untreated } \\
\text { Control } & \end{array}$ & 27.87 & 23.14 & 27.87 & 23.14 & 0.005820305 & 1.004042477 & \\
\hline B Neem -50 & & & 27.80 & 23.21 & 0.15 & 1.109747328 & \\
\hline C Neem -100 & & & 27.79 & 23.11 & 0.05 & 1.03763011 & \\
\hline D Phytase-50 & & & 25.16 & 23.21 & 2.78 & 6.852913751 & \\
\hline E Phytase-100 & & & 25.21 & 23.19 & 2.72 & 6.579690129 & \\
\hline $\begin{array}{c}\mathrm{F} \quad \text { Neem }(50)+ \\
\text { Phytase }(50)\end{array}$ & & & 24.53 & 23.20 & 3.41 & 10.60908541 & \\
\hline Hexo $\quad$ kinase & $\begin{array}{l}\text { Average } \\
\text { CT(target, } \\
\text { untreated) }\end{array}$ & $\begin{array}{l}\text { Average } \\
\text { CT(ref- } \\
\text { GAPDH, } \\
\text { untreated) }\end{array}$ & $\begin{array}{l}\text { Average } \\
\text { CT(target, } \\
\text { treated) }\end{array}$ & $\begin{array}{l}\text { Average } \\
\text { CT(ref- } \\
\text { GAPDH, } \\
\text { treated) }\end{array}$ & DeltaDeltaCT & $\begin{array}{l}\text { fold change } \\
\text { Expression }\end{array}$ & Gene \\
\hline $\begin{array}{cc}\text { A } & \text { Untreated } \\
\text { Control } & \end{array}$ & 28.85 & 23.14 & 28.85 & 23.14 & 0.005820305 & 1.004042477 & \\
\hline B Neem -50 & & & 28.83 & 23.21 & 0.10 & 1.07194526 & \\
\hline C Neem -100 & & & 28.92 & 23.11 & -0.09 & 0.937719529 & \\
\hline D Phytase-50 & & & 26.87 & 23.24 & 2.08 & 4.21846324 & \\
\hline E Phytase-100 & & & 26.25 & 23.17 & 2.64 & 6.224766159 & \\
\hline $\begin{array}{c}\mathrm{F} \text { Neem(50) }+ \\
\text { Phytase (50) }\end{array}$ & & & 26.23 & 23.27 & 2.76 & 6.760961275 & \\
\hline P19 & $\begin{array}{l}\text { Average } \\
\text { CT(target, } \\
\text { untreated })\end{array}$ & $\begin{array}{l}\text { Average } \\
\text { CT(ref- } \\
\text { GAPDH, } \\
\text { untreated) }\end{array}$ & $\begin{array}{l}\text { Average } \\
\text { CT(target, } \\
\text { treated) }\end{array}$ & $\begin{array}{l}\text { Average } \\
\text { CT(ref- } \\
\text { GAPDH, } \\
\text { treated) }\end{array}$ & DeltaDeltaCT & $\begin{array}{l}\text { fold change } \\
\text { Expression }\end{array}$ & Gene \\
\hline $\begin{array}{cc}\text { A } & \text { Untreated } \\
\text { Control } & \\
\end{array}$ & 27.43 & 23.14 & 27.43 & 23.14 & 0.007515044 & 1.005222622 & \\
\hline B Neem -50 & & & 27.24 & 23.21 & 0.27 & 1.207418636 & \\
\hline C Neem -100 & & & 27.17 & 23.11 & 0.24 & 1.182297721 & \\
\hline D Phytase- 50 & & & 27.37 & 23.24 & 0.16 & 1.117803928 & \\
\hline E Phytase-100 & & & 27.23 & 23.17 & 0.24 & 1.180758876 & \\
\hline $\begin{array}{l}\text { F Neem(50) }+ \\
\text { Phytase }(50)\end{array}$ & & & 26.90 & 23.27 & 0.67 & 1.589885779 & \\
\hline
\end{tabular}

Table :-2 The two-way ANOVA to express to the sum and mean value within the samples(control, Neem 50

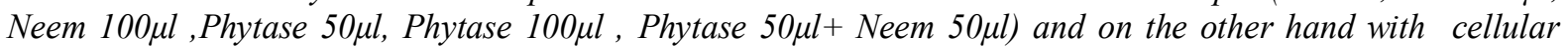
regulatory genes( $p 53, P 21, G-6-P, A L P, H . K . a n d P 19)$. 
International Journal of Engineering Applied Sciences and Technology, 2019

Vol. 4, Issue 6, ISSN No. 2455-2143, Pages 77-91

Published Online October 2019 in IJEAST (http://www.ijeast.com)

\begin{tabular}{|c|c|c|c|c|c|c|}
\hline & & Two-way Anova & & & & \\
\hline & & Sample & & & & \\
\hline Treatment & control & Neem 50 & Neem 100 & Phytase 50 & Phytase 100 & Phytase 50+Neem 50 \\
\hline p53 & 1 & 1.036587801 & 1.015021102 & 0.805707793 & 0.784383301 & $1 \quad 0.707847127$ \\
\hline p21 & 1.005164337 & 1.015255133 & 0.966947671 & 1.026923431 & 0.812044519 & 1.204838244 \\
\hline ALP & 1.004042477 & 1.109747328 & 1.03763011 & 6.852913751 & 6.579690129 & 10.60908541 \\
\hline$G \cdot 6 \cdot P$ & 1.169441995 & 1.181181966 & 1.030462675 & 4.779029025 & 4.310991272 & 7.659384077 \\
\hline Hexokinase & 1.004042477 & 1.07194526 & 0.937719529 & 4.21846324 & 6.224766159 & 6.760961275 \\
\hline P19 & 1.005222622 & 1.207418636 & 1.182297721 & 1.117803928 & 1.180758876 & 1.589885779 \\
\hline sum & 6.187913908 & 6.622136124 & 6.170078808 & 18.80084117 & 19.89263426 & 28.53200191 \\
\hline AVERAGE & 1.031318985 & 1.103689354 & 1.028346468 & 3.133473528 & 3.315439043 & 4.755333652 \\
\hline
\end{tabular}

Table: -3 the summary of the six samples indicates the sum, average mean, and variance within two-factor Without Replication.

\begin{tabular}{|c|c|c|c|c|}
\hline \multicolumn{5}{|c|}{ Anova: Two-Factor Without Replication } \\
\hline SUMMARY & Count & Sum & Average & Variance \\
\hline 1 & 5 & 4.349547124 & 0.869909425 & 0.021634959 \\
\hline 1.005164337 & 5 & 5.026008998 & 1.0052018 & 0.019800181 \\
\hline 1.004042477 & 5 & 26.18906673 & 5.237813346 & 16.98555362 \\
\hline 1.169441995 & 5 & 18.96104902 & 3.792209803 & 7.660674205 \\
\hline 1.004042477 & 5 & 19.21385546 & 3.842771093 & 7.611919852 \\
\hline 1.005222622 & 5 & 6.27816494 & 1.255632988 & 0.036007649 \\
\hline Neem 50 & 6 & 6.622136124 & 1.103689354 & 0.006026497 \\
\hline Neem 100 & 6 & 6.170078808 & 1.028346468 & 0.007190454 \\
\hline Phytase 50 & 6 & 18.80084117 & 3.133473528 & 6.327652341 \\
\hline Phytase 100 & 6 & 19.89263426 & 3.315439043 & 7.468146078 \\
\hline Phytase $50+$ Neem 50 & 6 & 28.53200191 & 4.755333652 & 17.14613715 \\
\hline
\end{tabular}

Table:-4 The Statistical analysis describe the highly significance in source of variation in the ROWs(The cellular regulatory gene) AND COLUMNS( Samples) and error Founded the sum square (SS),Degree of freedom (df), Mean of square (MS), F-Value $(F)$, and the P-value ( $p<0.05)$ highly significance 
International Journal of Engineering Applied Sciences and Technology, 2019

Vol. 4, Issue 6, ISSN No. 2455-2143, Pages 77-91

Published Online October 2019 in IJEAST (http://www.ijeast.com)

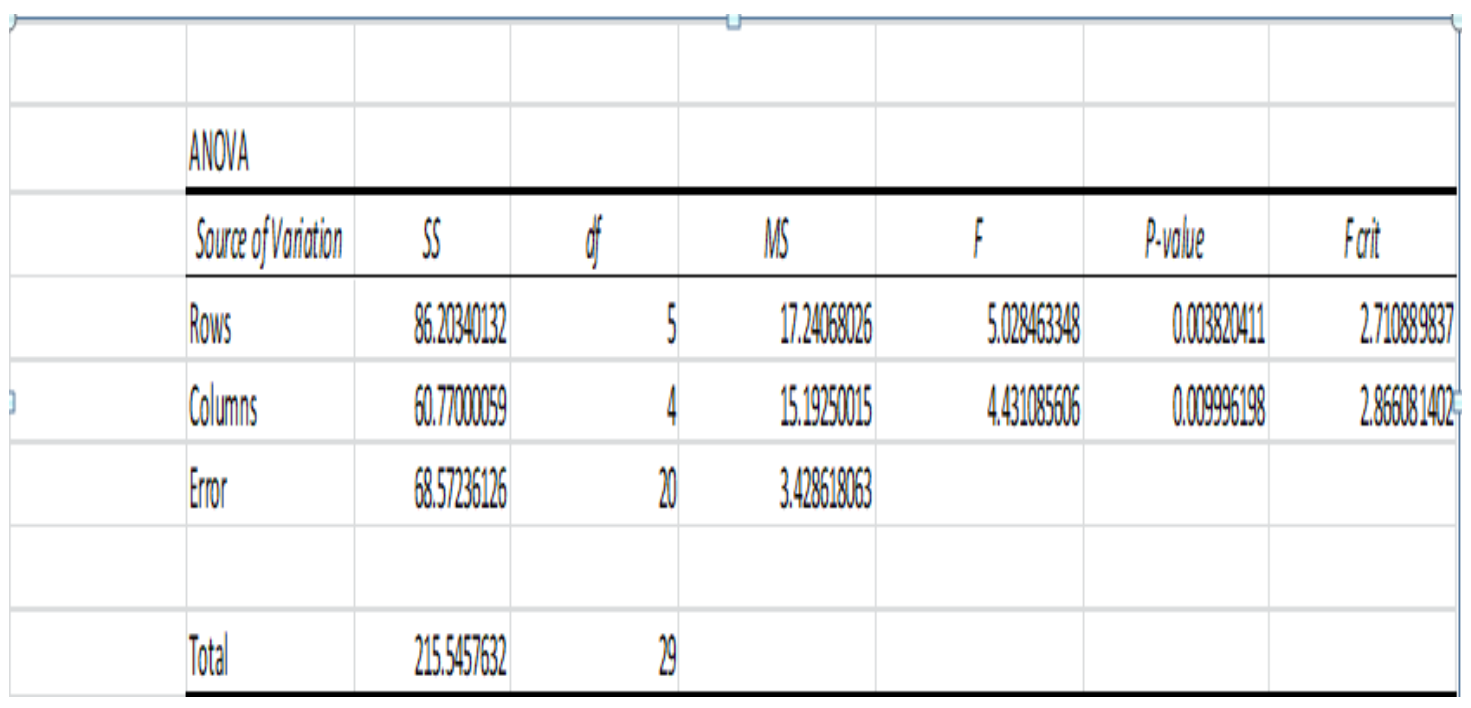

5.2 Alkaline phosphatase KIT (ALP)

ALP activity has been used to mean frequently mobile intestinal epithelial strains, but the intestinal AP can be handled with isoforms found in other tissues, cells and body fluids. cDNA and genes coding for a distinctive ALP bureaucracy have been cloned and can be used to collect particular samples to that extent theoretically. The alkaline phosphatase kit used to evaluate enzyme activity was performed at $100 \mu \mathrm{g}$ per protein blended sample With $900 \mu \mathrm{l}$ of alkaline phosphatase buffer kit and $50 \mu 1$ of Para Nitro phenol (substrate) added $5 \mu 1$ of ALP enzyme next to incubated overnight at $37^{\circ} \mathrm{c}$, yellow-colored enzyme activity was shown to be present and absorbance read at $405 \mathrm{~nm}$.

Table:-5 alkaline Phosphatase Enzyme Activity Reading by 570nm in the positive control 5nm paranitrophenol.

\begin{tabular}{|l|l|}
\hline & OD Reading 570nm \\
\hline Blank & 0 \\
\hline Positive Std control 0.150 ALP activity & 1.5 \\
\hline Neem 50 ALP activity & 0.035 \\
\hline Neem 100 ALP activity & 0.038 \\
\hline Phytase 50 ALP activity & 1.7 \\
\hline Phytase 100 ALP activity & 2.4 \\
\hline phytase 50 +Neem 50 ALP activity & 2.83 \\
\hline Sum & 8.503 \\
\hline Average & 1.214714286 \\
\hline
\end{tabular}

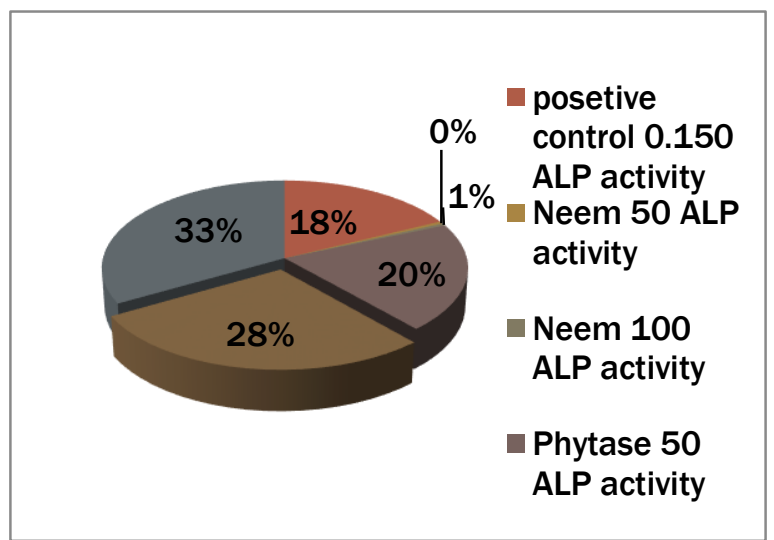

Fig:-4 the pie chart showed the variation of the positive control with each treatment groups of alkaline Phosphatase enzymatic activity in percent. 


\section{International Journal of Engineering Applied Sciences and Technology, 2019 \\ Vol. 4, Issue 6, ISSN No. 2455-2143, Pages 77-91 \\ Published Online October 2019 in IJEAST (http://www.ijeast.com)}

\section{DISCUSSION}

Phytate (6-myo-inositol phosphate) is the leading foundation of $\mathrm{P}$ current in plant kernels and is habitually an out of sorts' obtainable foundation of $P$ for monogastric. In totaling, phytate can interrelate by additional nutrients present-day in the nourishment, thus decreasing inorganic and protein immersion and growing endogenous damages. In line for to these destructive properties, phytate is accepted as an important antinutrient in broiler nourishments (Cowieson A. J et al., 2008). The objective of this research was to explore changes in the chicken embryonic cell line in the genome profiling with gene expression under circumstances of the metabolic pathway of phosphorus as seen in the activity of molecular genes and biochemical enzyme. During, in Chicken Cell line P53 gene expression product was statistically not significantly induced in response to Neem alone treatment, whereas in Phytase treatment, there was dose dependent decrease by 0.2 fold with and without Neem. In Chicken Cell line P21 gene expression was statistically not significantly induced in response to Neem alone treatment, whereas in Phytase treatment, there high dose showed decrease by 0.2 fold percent without Neem and increase by 0.2 fold percent with Neem In Chicken Cell line Glucose 6 phosphatase gene expression was statistically not significantly induced in response to Neem alone treatment, whereas in Phytase treatment, there was Dose dependent increase by 4.3 to 4.7 fold without Neem whereas 7.6 fold induction was found with Neem. In Chicken Cell line Hexokinase gene expression was statistically not significantly induced in response to Neem alone treatment, whereas in Phytase treatment, there was dose dependent increase by 4.2 to 6.2 fold without Neem whereas 6.7 fold induction was found with Neem. In Chicken Cell line P19 gene expression was statistically significantly induced in response to Neem alone treatment, Phytase treatment, there was dose dependent increase with and without Neem. In Chicken Cell line Alkaline Phosphatase gene expression was not significantly induced in response to Neem alone treatment, whereas in Phytase treatment, there was dose dependent increase by 6.5 to 6.8 fold without Neem whereas 10.6 fold induction was found with Neem. In the p53 and p21 gene cycling threshold value the cDNA amplification increases in treatment group control, neem $50 \mu \mathrm{l}$, neem $100 \mu \mathrm{L}$, phytase $50 \mu \mathrm{L}$, phytase $100 \mu \mathrm{L}$ and neem $50 \mu \mathrm{L}$ plus phytase 50 $\mu \mathrm{L}$; to the reverse the functional protein gene expression decreased respectively and the ALP, G6-P, Hexo kinase and p19 gene the cycling threshold value the cDNA amplification decreased in treatment group control, neem $50 \mu \mathrm{L}$, neem $100 \mu \mathrm{L}$, phytase $50 \mu \mathrm{L}$, phytase $100 \mu \mathrm{L}$ and neem $50 \mu \mathrm{L}$ plus phytase $50 \mu \mathrm{L}$, and the reciprocal the functional protein gene expression increased, Then the cDNA amplification cycling took short time was the functional protein gene expression higher product. The results was statistically high significant difference the control and all treatment group $p$-value $(p<0.005)$. And all of the cellular regulatory gene p53, p21, p19, ALP,G-6P,Hexa Kinase) also was statistically high significant difference $(\mathrm{p}<0.005)$.

In chicken cell line the enzyme activity Alkaline phosphatase shows the neem samples are less performance to compare positive control, the phytase 50 sample equal to positive control and the other phytase $100 \mu \mathrm{L}$ and neem mixed with phytase $50 \mu \mathrm{L}$ performance high than to positive control.

Then, Biochemical Estimation of Alkaline phosphatase shows that Phytase and Neem induces Alkaline Phosphatase due to generation of more Inorganic phosphate by Enzyme. Neem also plays an important position in strengthening the immune gadget of the frame. Enzymes were the largest monoclonal antibodies in the intestinal system and each pig was distinctive(Quaroni, A. (1986) Growth in antibodies in opposition to new castle and infectious bursal sickness viruses had been found when neem is incorporated in poultry feeds (Durrani Z (2008).Water based totally extract $(10 \%)$ of neem leaves is reported to have anti-viral houses in opposition to, chook pox, infectious bursal sicknesses (IBD) and Newcastle sickness virus (NDV) and it notably enhances the antibodies manufacturing in opposition to the IBD and NDV ( Sadekar RD et al., 1998). The prevailing have a look at turned into consequently designed to file the impact of A. indica on immunity of industrial broilers against New castle and infectious bursal sickness.

Neem, Supplementation, increase, Broiler, physiology, medicine, Antibacterial, historic. introduction many man made capsules and growth promoters are supplemented to the broilers to impact fast boom, however their use have proven many risks like excessive fee, destructive facet effect on fitness of birds and lengthy residual residences and many others. So, scientists are once more targeting the usage of our historic medicinal device to discover beneficial herbs and flora, which can be accurately used to boom the manufacturing. Certainly one of such vegetation, Neem (Azadirachta indica) is an indigenous plant of Asian subcontinent acknowledged for its useful medicinal residences considering that ancient instances. Neem has attracted world huge 


\section{International Journal of Engineering Applied Sciences and Technology, 2019 \\ Vol. 4, Issue 6, ISSN No. 2455-2143, Pages 77-91 \\ Published Online October 2019 in IJEAST (http://www.ijeast.com)}

prominence due to its giant variety of medicinal homes like antibacterial, antiviral, anti-fungal, antiprotozoal, hepatoprotective and numerous different properties without displaying any detrimental impacts (Kale, B.P et al., 2003).Also, neem promotes boom and feed efficiency of birds due to its antibacterial and hepato protective properties

\section{CONCLUSION}

The above conclusion indicate that in intestinal Broiler Chicken cells Phytase and Neem involvement of Cell Cycle regulatory genes P53 and p21 are involved to lesser extent in Phosphate Metabolism, whereas Glucose 6 phosphate, Hexokinase and Alkaline Phosphatase are the direct targets of Phosphate Metabolism.

Hence use of Phytase and Neem extract in diet of Chickens can be beneficial to generate less Phosphorous waste and protecting

Pollution and improve the utilization, digestion of feed ingredients, reduced wastage of other feeds nutrient and reduced costs of supplementary feed in good quality of chicken growth. Now that the gene expression and enzymatic activity with the sample of phytase and neem extract done in vitro chicken cell line successfully achieved, in the future recommend will be practice in vivo methods for the demonstration of all regulatory genes it should be possible to obtain further insights in the function of phosphorylation pathway in the metabolism of cells.

\section{ACKNOWLEDGMENT}

I wish to express sincere gratitude to my academic guide, and my advisors, Dr. Pankaj Taneja Department of Biotechnology, School of engineering and Technology in Sharda University, India for his supports, encouragement, and trust throughout my M.Tech programme. His concerns, patience, and generosity are greatly appreciated.

Finally, I would like to express special thanks to my wife, Muluken Feneta, and to my parents and daughters for their inspiration, support, and constant encouragement throughout my studies.

\section{REFERENCES}

1. Agyekum, A. K., Sands, J. S., Regassa, A., Kiarie, E., Weihrauch, D., Kim, W. K., \& Nyachoti, C. M. (2015). Effect of supplementing a fibrous diet with a xylanase and $\beta$-glucanase blend on growth performance, intestinal glucose uptake, and transport-associated gene expression in growing pigs. Journal of animal science, 93(7) pg3483-3493.

2. Ahmed, F., Rahman, M. S., Ahmed, S. U., \& Miah, M. Y. (2004). Performance of broiler on phytase supplemented soybean meal based diet. International Journal of Poultry Science, 3(4) pg266-271.

3. Alders, R. G., \& Pym, R. A. E. (2009). Village poultry: still important to millions, eight thousand years after domestication. World's Poultry Science Journal, 65(2) pg181-190.

4. Alers, S., Löffler, A. S., Wesselborg, S., \& Stork, B. (2012). Role of AMPK-mTORUlk1/2 in the regulation of autophagy: cross talk, shortcuts, and feedbacks. Molecular and cellular biology, 32(1) pg 2-11.

5. Brenes, A., Guenter, W., Marquardt, R. R., \& Rotter, B. A. (1993). Effect of $\beta$ glucanase/pentosanase enzyme supplementation on the performance of chickens and laying hens fed wheat, barley, naked oats and rye diets. Canadian Journal of Animal Science, 73(4) pg 941-951.

6. Brenes, A., Smith, M., Guenter, W., \& Marquardt, R. R. (1993). Effect of enzyme supplementation on the performance and digestive tract size of broiler chickens fed wheat-and barley-based diets. Poultry science, 72(9), 1731-1739.

7. Cowieson, A. J., Acamovic, T., \& Bedford, M. R. (2004). The effects of phytase and phytic acid on the loss of endogenous amino acids and minerals from broiler chickens. British poultry science, 45(1), 101108.

8. Cowieson, A. J., Ravindran, V., \& Selle, P. H. (2008). Influence of dietary phytic acid and source of microbial phytase on ileal endogenous amino acid flows in broiler chickens. Poultry Science, 87(11), 2287-2299.

9. Csorba, T., Pantaleo, V., \& Burgyán, J. (2009). RNA silencing: an antiviral 


\section{International Journal of Engineering Applied Sciences and Technology, 2019 \\ Vol. 4, Issue 6, ISSN No. 2455-2143, Pages 77-91 \\ Published Online October 2019 in IJEAST (http://www.ijeast.com)}

mechanism. In Advances in virus research (Vol. 75, pp. 35-230). Academic Press.

10. CU, P., \& GAO, C. F. (2009). Progress and insight of miRNA on hepatocellular carcinoma. China Biotechnology, 28(12), 94101.

11. Durrani, F. R., Sultan, A., Jan, M., Chand, N., \& Durrani, Z. (2007). Immunomodulatory and growth promoting effects of Neem (Azadirachta indica) leaves infusion in broiler chicks. Sar J Agric.

12. Falowo, A. B. (2015). Effects of natural antioxidants and thermal treatment on quality of meat from Bonsmara and non-descripts cattle (Doctoral dissertation, University of Fort Hare).

13. Gilbert, E. R., Li, H., Emmerson, D. A., Webb Jr, K. E., \& Wong, E. A. (2008). Dietary protein quality and feed restriction influence abundance of nutrient transporter mRNA in the small intestine of broiler chicks. The Journal of nutrition, 138(2) pg 262-271.

14. Gilbert, E. R., Wong, E. A., \& Webb Jr, K. E. (2008b). Board-invited review: peptide absorption and utilization: implications for animal nutrition and health. Journal of animal science, 86(9) pg 2135-2155.

15. Hendriks, G., Derr, R. S., Misovic, B., Morolli, B., Calleja, F. M., \& Vrieling, H. (2015). The extended ToxTracker assay discriminates between induction of DNA damage, oxidative stress, and protein misfolding. Toxicological Sciences, 150(1) pg 190-203.

16. Hipper, C., Brault, V., Ziegler-Graff, V., \& Revers, F. (2013). Viral and cellular factors involved in phloem transport of plant viruses. Frontiers in plant science, 4 pg 154.

17. Hooge, D. M., Pierce, J. L., McBride, K. W., \& Rigolin, P. J. (2010). Meta-analysis of broiler chicken trials using diets with or without Allzyme® SSF Enzyme Complex®. International Journal of Poultry Science, 9(9) pg 819-823.

18. Kalantar, M., Khajali, F., \& Yaghobfar, A. (2016). Effect of cereal type and enzyme addition on performance, pancreatic enzyme activity, intestinal microflora and gut morphology of broilers. Poultry Science Journal, 4(1) pg 63-71.
19. Kale, B. P., Kothekar, M. A., Tayade, H. P., Jaju, J. B., \& Mateenuddin, M. (2003). Effect of aqueous extract of Azadirachta indica leaves on hepatotoxicity induced by antitubercular drugs in rats. Indian Journal of Pharmacology, 35(3) pg 177-180.

20. Kaya, M., Küçükyumuk, Z., \& Erdal, I. (2009). Phytase activity, phytic acid, zinc, phosphorus and protein contents in different chickpea genotypes in relation to nitrogen and zinc fertilization. African Journal of Biotechnology, 8(18). pg pp. 4508-4513

21. Kryger, K. N., Thomsen, K., Whyte, M., \& Dissing, M. (2010). Smallholder poultry production: Livelihoods, food security and sociocultural significance.Global Food Security, 15 pg 53-52.

22. Lamid, M., Al-Arif, A., Asmarani, O., \& Warsito, S. H. (2018, April). Characterization of phytase enzymes as feed additive for poultry and feed. In IOP Conference Series: Earth and Environmental Science (Vol. 137, No. 1, p. 012009). IOP Publishing.

23. Mahejabin, N., Mostofa, M., Akter, F., Das, S., \& Alam, M. (2015). Effects of Neem, turmeric and papaya leaf extract mixture on growth performance of broilers. International Journal of Natural and Social Sciences, 2(2) pg 17-21.

24. Morse, D., Head, H. H., \& Wilcox, C. J. (1992). Disappearance of phosphorus in phytate from concentrates in vitro and from rations fed to lactating dairy cows. Journal of Dairy Science, 75(7) pg1979-1986.

25. National Research Council. (1994). Nutrient requirements of poultry: 1994. National Academies Press.

26. Olukosi, O. A., Cowieson, A. J., \& Adeola, O. (2008). Energy utilization and growth performance of broilers receiving diets supplemented with enzymes containing carbohydrase or phytase activity individually or in combination. British Journal of Nutrition, 99(3) pg682-690.

27. Quaroni, A. (1986). Crypt cell antigen expression in human colon tumor cell lines: analysis with a panel of monoclonal antibodies to $\mathrm{CaCo}-2$ luminal membrane components. JNCI: Journal of the National Cancer Institute, 76(4) pg571-585. 


\section{International Journal of Engineering Applied Sciences and Technology, 2019 \\ Vol. 4, Issue 6, ISSN No. 2455-2143, Pages 77-91 \\ Published Online October 2019 in IJEAST (http://www.ijeast.com)}

28. Ravindran, V., Selle, P. H., Ravindran, G., Morel, P. C. H., Kies, A. K., \& Bryden, W. L. (2001). Microbial phytase improves performance, apparent metabolizable energy, and ileal amino acid digestibility of broilers fed a lysine-deficient diet. Poultry Science, 80(3) pg338-344.

29. Sadekar, R. D., Kolte, A. Y., Barmase, B. S., \& Desai, V. F. (1998). Immunopotentiating effects of Azadirachta indica (Neem) dry leaves powder in broilers, naturally infected with IBD virus. Indian journal of experimental biology, 36(11) pg1151-1153.

30. Schmutterer, H. (1990). Future tasks of neem research in relation to agricultural needs worldwide. ARS-US Department of Agriculture, Agricultural Research Service (USA). Selle P H and Ravindran V 2007 Anim. Feed Sci. Tech. pg35 1-41.

31. Selle, P. H., \& Ravindran, V. (2007). Microbial phytase in poultry nutrition. Animal feed science and technology, 135(1-2), pg141.

32. Siddik, Z. H. (Ed.). (2010). Checkpoint controls and targets in cancer therapy. Springer Science \& Business Media.

33. Singh, P. K. (2008). Significance of phytic acid and supplemental phytase in chicken nutrition: a review. World's Poultry Science Journal, 64(4), pg553-580.

34. Slominski, B. A. (2011). Recent advances in research on enzymes for poultry diets. Poultry Science, 90(9), pg2013-2023.

35. Su, W., Hopkins, S., Nesser, N. K., Sopher, B., Silvestroni, A., Ammanuel, S., ... \& Garden, G. A. (2014). The p53 transcription factor modulates microglia behavior through microRNA-dependent regulation of cMaf. The Journal of Immunology, 192(1), 358-366.
36. Tamim, N. M., Angel, R., \& Christman, M. (2004). Influence of dietary calcium and phytase on phytate phosphorus hydrolysis in broiler chickens. Poultry science, 83(8) pg1358-1367.

37. Tizziani, T., Donzele, R. F. M. D. O., Donzele, J. L., Balbino, E. M., Silva, A. D., Figueiredo, É. M. D., ... \& Jacob, R. D. F. (2016). Available phosphorus levels in diets supplemented with phytase for male broilers aged 22 to 42 days kept in a high-temperature environment. Revista Brasileira de Zootecnia, 45(2) pg48-55.

38. Várallyay, É., Lichner, Z., Sáfrány, J., Havelda, Z., Salamon, P., Bisztray, G., \& Burgyán, J. (2010). Development of a virus induced gene silencing vector from a legumesinfectingtobamovirus. Acta Biologica Hungarica, 61(4) pg457-469.

39. Wang Z, et al. RNA-Seq: a revolutionary tool for transcriptomics, Nat. Rev. Genet, 2009, vol. 10 pg. 57-63)

40. Wong, J.T., de Bruyn, J., Bagnol, B., Grieve, H., Li, M., Pym, R., Alders, R.G., 2017. Small-scale poultry in resource-poor settings: a review. Glob. Food Security 15 pg43-52.

41. Woyengo, T. A., \& Nyachoti, C. M. (2013). anti-nutritional effects of phytic acid in diets for pigs and poultry-current knowledge and directions for future research. Canadian Journal of Animal Science, 93(1) pg9-21..

42. Yang, Y. Y., Fan, Y. F., Cao, Y. H., Guo, P. P., Dong, B., \& Ma, Y. X. (2017). Effects of exogenous phytase and xylanase, individually or in combination, and pelleting on nutrient digestibility, available energy content of wheat and performance of growing pigs fed wheat-based diets. Asian-Australasian journal of animal sciences, 30(1), pg57-63. 